\title{
Patterns of Fine-Scale Spatial Genetic Structure and Pollen Dispersal in Giant Sequoia (Sequoiadendron giganteum)
}

\author{
Rainbow DeSilva *(D) and Richard S. Dodd \\ Deptartment of Environmental Science, Policy, and Management, University of California, \\ Berkeley, CA 94720, USA; dodd@berkeley.edu \\ * Correspondence: rainbow222@berkeley.edu
}

check for updates

Citation: DeSilva, R.; Dodd, R.S. Patterns of Fine-Scale Spatial Genetic Structure and Pollen Dispersal in Giant Sequoia (Sequoiadendron giganteum). Forests 2021, 12, 61. https://doi.org/10.3390/f12010061

Received: 10 December 2020 Accepted: 4 January 2021 Published: 7 January 2021

Publisher's Note: MDPI stays neutral with regard to jurisdictional clai$\mathrm{ms}$ in published maps and institutional affiliations.

Copyright: (C) 2021 by the authors. Licensee MDPI, Basel, Switzerland. This article is an open access article distributed under the terms and conditions of the Creative Commons Attribution (CC BY) license (https:// creativecommons.org/licenses/by/ $4.0 /)$.

\begin{abstract}
Research Highlights: Patterns of dispersal shape the distribution and temporal development of genetic diversity both within and among populations. In an era of unprecedented environmental change, the maintenance of extant genetic diversity is crucial to population persistence. Background and Objectives: We investigate patterns of pollen dispersal and spatial genetic structure within populations of giant sequoia (Sequoiadendron giganteum). Materials and Methods: The leaf genotypes of established trees from twelve populations were used to estimate the extent of spatial genetic structure within populations, as measured by the Sp statistic. We utilized progeny arrays from five populations to estimate mating parameters, the diversity of the pollen pool, and characteristics of pollen dispersal. Results: Our research indicates that giant sequoia is predominantly outcrossing, but exhibits moderate levels of bi-parental inbreeding (0.155). The diversity of the pollen pool is low, with an average of 7.5 pollen donors per mother tree. As revealed by the Sp-statistic, we find significant genetic structure in ten of twelve populations examined, which indicates the clustering of related individuals at fine spatial scales. Estimates of pollen and gene dispersal indicate predominantly local dispersal, with the majority of pollen dispersal $<253 \mathrm{~m}$, and with some populations showing fat-tailed dispersal curves, suggesting potential for long-distance dispersal. Conclusions: The research presented here represent the first detailed examination of the reproductive ecology of giant sequoia, which will provide necessary background information for the conservation of genetic resources in this species. We suggest that restoration planting can mitigate potential diversity loss from many giant sequoia populations.
\end{abstract}

Keywords: pollen dispersal; spatial genetic structure; bi-parental inbreeding; giant sequoia

\section{Introduction}

Propagule/regeneration dispersal is a key ecological process that influences the evolution of genetic diversity both within and among populations [1-4]. For sessile organisms such as forest trees, how far propagules disperse away from the parent tree has many consequences for the distribution of genetic diversity at fine-spatial scales [5]. Moreover, the characteristics of the dispersal kernel play a large role in determining the extent of long-distance dispersal (gene flow), and thus modulate large scale patterns of genetic diversity and structure across a species range [6-8]. Since an adequate pool of genetic diversity, on which selection can act, is critical for the success of populations under changing environments, understanding dispersal dynamics is important for successful management of species.

At the scale of a population, dispersal dynamics shape the clustering of related individuals on the landscape. Fine-scale spatial genetic structure (FSGS) can be defined as the non-random arrangement of genotypes on a landscape [5,9]. In plants, FSGS is caused by the interplay of many evolutionary forces, but of key importance is dispersal limitation, which creates patterns of isolation by distance between parents and offspring $[5,10]$. When related genotypes aggregate together in space, this can increase rates of bi-parental 
inbreeding, eventually leading to a reduction in genetic diversity (i.e., loss of heterozygosity) [11,12]. Moreover, populations with high levels of fine-scale genetic structure can be more vulnerable to genetic diversity loss from stochastic events, such as disturbance or genetic drift [13].

In plants, gene dispersal occurs in two distinct phases, pollen and subsequent seed dispersal. For forest trees, pollen and seed differ in abundance and dispersal dynamics. Empirical studies have often shown that for wind-dispersed species, pollen can have particularly large dispersal potential [14-17]. Moreover, the shape of the dispersal kernel (kurtosis) is an important indicator of the potential for long-distance dispersal (LDD), as fat-tailed curves have an increased likelihood of LDD [1]. In an era of ever-increasing risks of catastrophic mortality in populations due to wildfires and disease, exacerbated in species with small, disjunct populations, long-distance pollen dispersal can be especially important for maintaining connectivity among habitat patches $[18,19]$ and mitigating risks of inbreeding. Thus, determining the characteristics of the pollen dispersal curve is critical in order to understanding how genetic diversity will change within populations and across fragmented landscapes.

Giant sequoia, Sequoiadendron giganteum, is a paleoendemic long-lived tree species occupying $~ 70$ groves, scattered across mid-elevations in the Sierra Nevada mountains of California [20]. Its range stretches approximately $400 \mathrm{~km}$ from Placer county in the north to Tulare county in the south. The entire range of giant sequoia is fragmented. However, populations tend to become smaller and more disjunct in the northern $\sim 2 / 3 \mathrm{rds}$ of the latitudinal range (Figure 1). Giant sequoia is wind-pollinated, and mature trees produce an abundance of pollen and seed cones each year [21]. Mature seed cones remain closed and attached to the tree for many years, and thus provide a large aerial seed bank [21]. Successful regeneration for this species often occurs after fires, which trigger seed dispersal and create canopy gaps [22-26]. This species' reliance on fire highlights a potential for environmental mismatch, as forest management policies and shifting climate alter fire regimes across California [27]. In addition, climate change places additional stress on many forest tree populations, as demonstrated by the massive tree mortality that resulted from a recent drought in the Sierra Nevada mountains.

Given the cultural and ecological value of giant sequoia, it is surprising how little is known regarding the fine-scale patterns of genetic diversity and dispersal within the extant groves. To date, no studies have addressed the extent of FSGS within giant sequoia populations, and only a single study [28], which investigated pollen rain, demonstrated patterns consistent with short-distance pollen dispersal. However, the scope of this work was extremely limited as it only covered two extremely small populations of giant sequoia $<0.21 \mathrm{~km}^{2}$ [27]. Our previous work indicated minimal gene exchange between adjacent groves (3.0-6.5 km apart) in the northern range of giant sequoia [29], consistent with limited dispersal in the species. However, no studies have used progeny arrays at a local scale to understand the dynamics of pollen dispersal distance, the quality (diversity) of the pollen pool, and rates of inbreeding, in determining FSGS. These are factors that are crucial in shaping how genetic diversity may change over time. Here we attempt to fill this gap in giant sequoia reproductive ecology by doing the following: (1) determining the degree of fine-scale spatial genetic structure within twelve populations of giant sequoia; (2) estimating mating parameters (i.e., number of pollen donors, rates of outcrossing and bi-parental inbreeding) using progeny collected from five populations; and (3) investigating characteristics of pollen dispersal, including the mean dispersal distance and kurtosis of the dispersal curve. 


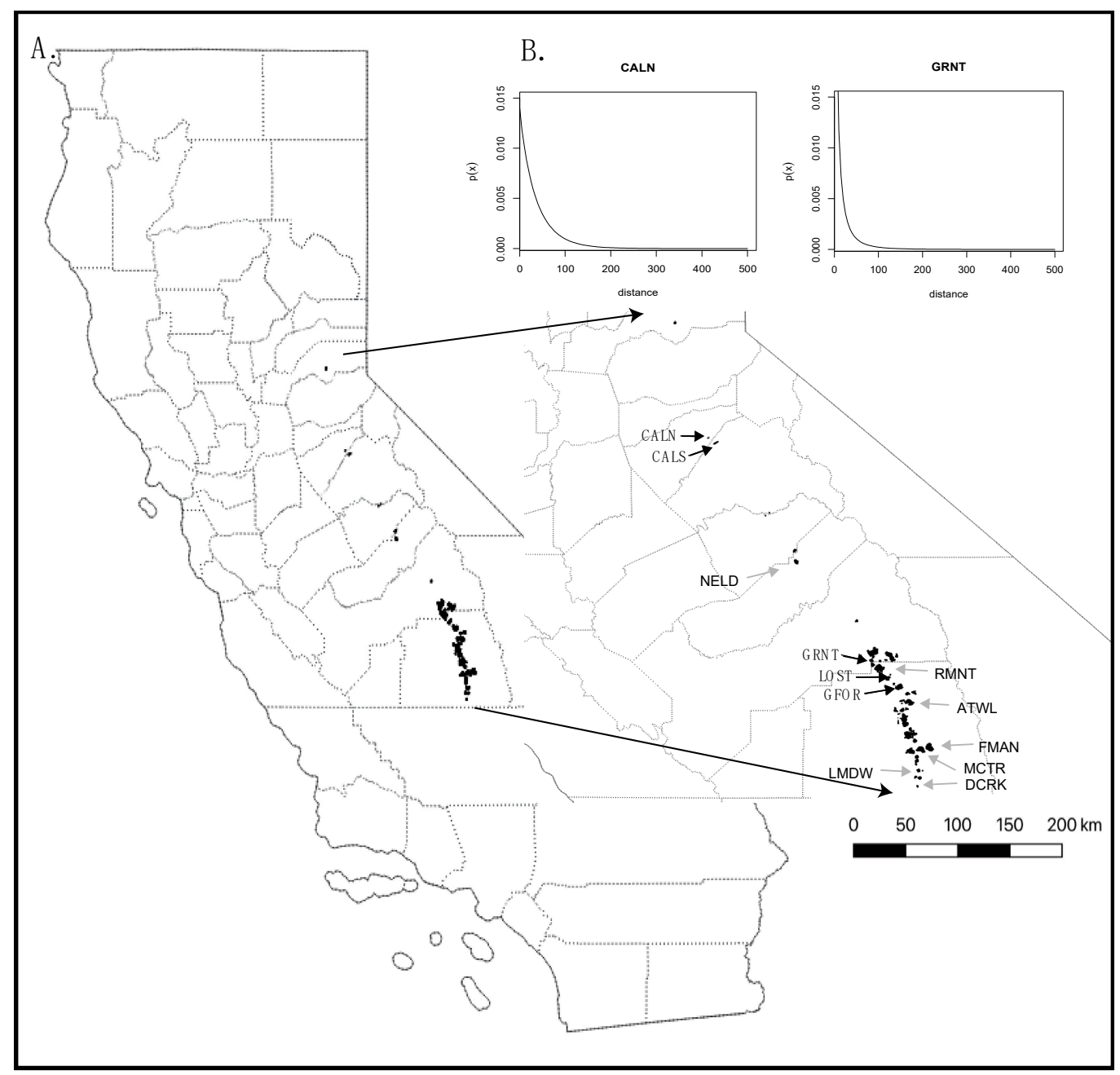

Figure 1. (A) Range map of giant sequoia. Populations where leaf or seed collection occurred are noted by a population code. Leaf tissue was collected in all noted locations, black arrows indicate seed collection sites. (B) Pollen dispersal kernels for two giant sequoia populations, CALN (left) and GRNT (right) estimated in TwoGener by fitting an exponential power distribution with effective density set to $\frac{1}{2}$ census density.

\section{Materials and Methods}

\subsection{Sampling and Data Preparation}

\subsubsection{Fine-Scale Spatial Genetic Structure (FSGS)}

FSGS within groves was estimated using leaf tissue collected from twelve giant sequoia groves (Figure 1). Leaf collections, DNA extraction, and DNA preparation are described in detail in DeSilva and Dodd [29]. In brief, for this study we utilized leaf material collected in twelve populations with high sampling density. All individuals were genotyped at ten microsatellite loci, as described in DeSilva and Dodd [30].

\subsubsection{Mating Parameters and Pollen Dispersal}

We obtained seeds from fallen cones that were in clusters close to a putative parent tree, within five $S$. giganteum groves (Figure 1). Due to the height of reproductive branches in mature $S$. giganteum trees, often $>10 \mathrm{~m}, 0.5-2.0$ bushels of cones were collected from the ground beneath potential maternal trees in 7-18 locations per population (Table 1). The geographic coordinates of all collection sites were taken at the time of collection. From each sampling location, seeds were extracted from multiple cones from each sampling location and mixed together. We then randomly chose 100 seeds from each collection location and 
subjected them to 30 days of moist cold-stratification and 30 days of dry cold-stratification at $1-2^{\circ}$ Celsius. After stratification, seeds were then germinated on filter-paper-lined Petri dishes. Subsequently, DNA was isolated from the seedling radicle using the CTAB method [31]. A total of 1070 seeds were germinated and genotyped using ten microsatellite markers outlined in DeSilva and Dodd [30] (Appendix A).

Table 1. Seed collection and mating system parameters for five populations.

\begin{tabular}{cccccccc}
\hline $\begin{array}{c}\text { Population } \\
\text { (ha) }\end{array}$ & $\begin{array}{c}\text { Seed } \\
\text { Collection } \\
\text { Sites }\end{array}$ & $\begin{array}{c}\text { Average } \\
\text { Maternal } \\
\text { Family Size }\end{array}$ & $\begin{array}{c}\text { Census } \\
\text { Density } \mathbf{( m}^{2} \text { ) }\end{array}$ & $\begin{array}{c}\text { Multi-Locus } \\
\text { Outcrossing Rate: } \\
\mathbf{t}_{\mathbf{m}} \text { (SD) }\end{array}$ & $\begin{array}{c}\text { Single-Locus } \\
\text { Outcrossing } \\
\text { Rate: } \mathbf{t}_{\mathbf{s}} \text { (SD) }\end{array}$ & $\begin{array}{c}\text { Bi-Parental } \\
\text { Inbreeding: } \\
\mathbf{t}_{\mathbf{m}}-\mathbf{t}_{\mathbf{s}}\end{array}$ & $\begin{array}{c}\text { Nep } \\
\text { (SD }\end{array}$ \\
\hline CALN (25) & 7 & 10 & 0.0005 & $0.92(0.11)$ & $0.81(0.09)$ & $0.117(0.09)$ & 8.5 \\
CALS (182) & 9 & 11 & 0.0006 & $0.94(0.12)$ & $0.76(0.04)$ & $0.178(0.11)$ & 8.4 \\
GRNT (163) & 11 & 14 & 0.0010 & $0.84(0.03)$ & $0.66(0.03)$ & $0.180(0.03)$ & 4.7 \\
LOST (21) & 8 & 13 & 0.0018 & $0.88(0.04)$ & $0.77(0.04)$ & $0.112(0.04)$ & 7.8 \\
GFOR (935) & 18 & 12 & 0.0010 & $0.95(0.12)$ & $0.76(0.02)$ & $0.189(0.11)$ & 7.0 \\
AVERAGE & - & - & - & 0.91 & 0.75 & 0.155 & 7.5 \\
\hline
\end{tabular}

The census density of mature trees was estimated from population surveys for all southern groves, using the density of all trees $>75 \mathrm{~cm}$ diameter at breast height [32]. For the northern groves, (NELD, CALN, CALS), census densities of mature trees were estimated from Willard [20].

\subsubsection{Assigning Maternity}

Because each cone collection locality potentially included progeny from more than a single mother tree, maternal families were identified using the likelihood method implemented in ML-RELATE [33]. Subsequently, the largest maternal families were retained from each cone collection locality. We then removed individuals with potential null alleles or genotyping errors (those that were incompatible with a single mother tree), while maximizing the number of individuals retaining the most common alleles within the maternal family. On occasion, this process resulted in more than one potential maternal family. In this case, all potential families were retained for subsequent analyses and average statistics for the population are reported. We then utilized MLTR to determine the most likely maternal genotype for each maternal family [34,35], as potential maternal genotypes were not sampled. After filtering, DNA from 629 seeds was used in pollen dispersal analyses and in assessing mating parameters.

\subsection{Data Analysis}

\subsubsection{Mating Parameters}

Using the seed genotype data, we first estimated the mating parameters (selfing, bi-parental inbreeding and outcrossing) from single-locus and multilocus estimates of outcrossing using MLTR [35]. The multilocus outcrossing rate $\left(t_{m}\right)$ provides an estimate of the true level of selfing, whereas the single-locus outcrossing rate $\left(t_{s}\right)$ accounts for all inbreeding (selfing and mating with close relatives). Thus, we estimated bi-parental inbreeding as $\left(t_{m}-t_{s}\right)$, following Ritland [35].

Then, we used TwoGener [36] to estimate the effective number of pollen donors per mother tree $\left(\mathrm{N}_{\mathrm{ep}}\right)$ as $\mathrm{N}_{\mathrm{ep}}=1 / 2 \Phi F T$ [37], where $\Phi F T$ is the differentiation between the pollen clouds sampled by pairs of maternal trees within a population (for details on TwoGener, see Spatial genetic structure and gene dispersal below).

\subsubsection{Spatial Genetic Structure and Gene Dispersal}

Based on the leaf genotypes of established trees, we estimated the extent of the spatial genetic structure within populations using the Sp statistic [5], calculated as $-b \mathrm{~F} /\left[1-\mathrm{F}_{(1)}\right]$, where $b \mathrm{~F}$ represents the linear decay in the pairwise kinship coefficient $\left(\mathrm{F}_{\mathrm{ij}}\right)$ for all pairs of individuals with the logarithm of geographic distance, and $F_{(1)}$ is the mean kinship 
coefficient between individuals within the first distance class. The Sp statistic is useful in our case because it provides a meaningful way to compare spatial genetic structure across populations despite variations in population sizes and sampling scheme [5]. For this calculation, we used the pairwise kinship coefficients $\left(\mathrm{F}_{\mathrm{ij}}\right)$ of Loiselle et al. [38], as this measure of relatedness shows less statistical bias than many others [5,39]. We assigned the number of distance classes based on the geographic area of each grove as follows: number of distance classes $0-125$ ha $=2,125-275$ ha $=3,275-500$ ha $=4,500-850$ ha $=5$, and $>900$ ha $=6$ (Appendix B). We determined these grove area cut-offs, after completing exploratory analyses, to inform the spatial resolution that allowed for a large number of pairwise comparisons per distance class and an adequate spatial resolution within the first distance class. The significance of ' $b \mathrm{~F}^{\prime}$ ' was obtained using 20,000 permutations of sampling locations within populations. All calculations were completed using SPAGeDi 1.5 software [40].

In addition, we utilized SPAGeDi 1.5 [40] to obtain an indirect estimate of evolutionaryscale gene dispersal, an effective pollen and seed average, from patterns of FSGS. Under equilibrium isolation-by-distance conditions, the scale of effective gene dispersal can be estimated from Wright's neighborhood size equation $\left(\mathrm{N}_{\mathrm{b}} \equiv 4 \pi \mathrm{De}^{2}\right)$, where $\mathrm{D}_{\mathrm{e}}$ is the effective density and $\sigma^{2}$ is half the mean-squared parent-offspring distance (i.e., gene dispersal; $[40,41])$. For the estimation of gene dispersal $\left(\sigma^{2}\right)$, we set the effective density to $1 / 2$ the adult census density. We recognize this represents a high estimate of effective density, as evidence suggests that for adult populations the ratio of $\mathrm{Ne} / \mathrm{N}$ often ranges between 0.1 and 0.5 [42]. We also utilized correlation tests to determine the relationships between gene dispersal with census population size and population density.

\subsubsection{Pollen Dispersal Parameters}

We estimated the characteristics of pollen dispersal using both the TwoGener and KinDist approaches, as implemented in POLDISP 1.0 [43]. Here, maternal trees are considered to serve as pollen traps, and their progeny represent a sample of the available pollen pool. The TwoGener method uses the differential structure of the pollen sampled by each mother tree across the landscape [36], whereas the related KinDist method uses the relationship between correlated paternity and the pollen dispersal kernel [44]. Both methods can have some drawbacks. To fit the pollen dispersal curve, TwoGener requires an independent estimate of effective density which can be hard to obtain for some species. Yet, accuracy can be increased with a reliable external estimate of effective density [44]. On the other hand, KinDist requires a threshold distance for unrelated pollen pools, which can be difficult to determine. For both KinDist and TwoGener, we applied the two parameter ( $a$ and $b$ ) exponential power distribution to fit the pollen distribution curve, as recommended by Austerlitz et al. [45]. This distribution allows for the leptokurtic pattern of pollen dispersal that is commonly observed in wind-pollinated trees [16,17,45-48]. We estimated the scale (a) and shape (b) parameters of the dispersal kernel and calculated mean pollen dispersal distances (d) according to Austerlitz et al. [45]. The shape parameter (b) provides an indication of the potential for LDD, through determining the degree of kurtosis (i.e., how fat-tailed the dispersal curve is). For TwoGener calculations we set the $\mathrm{Ne} / \mathrm{N}$ ratios as 0.1 and 0.5 . Because effective density often ranges between 0.1 and 0.5 of the census density [42], we chose these values as they potentially represent a high and low estimate of the effective density within giant sequoia populations.

\section{Results}

\subsection{Mating Parameters}

The average multi-locus outcrossing rate $\left(t_{m}\right)$ across five groves was $91 \%$, with the highest outcrossing observed in GFOR (0.95) and the lowest in GRNT (0.84) (Table 1), which indicates that low levels ( $9 \%$ ) of selfing are also occurring. The average rate of bi-parental inbreeding was moderate $\left(t_{m}-t_{s}\right)=0.155$. Bi-parental inbreeding was lowest in LOST, $\left(t_{m}-t_{s}\right)=0.112(0.037)$, and highest in GFOR, $\left(t_{m}-t_{s}\right)=0.189(0.107)$ (Table 1). 
The number of effective pollen donors per mother tree $\left(\mathrm{N}_{\mathrm{ep}}\right)$ ranged from 4.7 to 8.5 , with an average of 7.5 (Table 1). We observed the fewest pollen donors in GRNT (4.7) and the most in CALN (8.5) (Table 1).

\subsection{Spatial Genetic Structure}

Significant genetic structure was found in ten of the twelve populations assessed (Table 2). For these ten populations, the Sp ranged from 0.024 to 0.044 , and was lowest in RMNT and highest in CALS. When estimating Wright's gene dispersal from SPAGeDi, which represents an effective pollen and seed average, we found mean gene dispersal distances between 120.4 and $374.0 \mathrm{~m}$ (Table 2). Our iterative procedure to estimate gene dispersal failed to converge for three populations, which was likely due to the insufficient sampling density within these populations. Although we found a significant negative correlation between gene dispersal and grove size in hectares, we did not detect any significant correlations between gene dispersal and census population size or census population density. We believe that grove size is not a reliable index of the presence of giant sequoia on the landscape because grove boundaries may include large areas not occupied by the species, such as Nelder grove, which comprises two groups of spatially distinct trees.

Table 2. Sp-statistic and estimated gene dispersal for twelve giant sequoia populations distributed across the range, based on analyses using SPAGeDi [40].

\begin{tabular}{ccc}
\hline Population (ha) & Sp-Statistic & Sigma*2 $(\mathbf{m})^{*}$ \\
\hline CALN (25) & $0.0354^{*}$ & 252.6 \\
CALS (182) & $0.0444^{* *}$ & 374.0 \\
NELD (195) & $0.0417^{* *}$ & 153.6 \\
GRNT (163) & $0.0388^{* *}$ & - \\
RMNT (1466) & $0.0235^{*}$ & 120.4 \\
LOST (21) & $0.0339^{\mathrm{NS}}$ & - \\
GFOR (935) & $0.0238^{* *}$ & 185.6 \\
ATWL (542) & $0.0292^{\mathrm{NS}}$ & - \\
MCTR (700) & $0.0414^{* *}$ & 264.2 \\
FMAN (580) & $0.0397^{* *}$ & 159.0 \\
LMDW (138) & $0.0308^{*}$ & 260.2 \\
DCRK (21) & $0.0303^{*}$ & 236.0 \\
\hline
\end{tabular}

${ }^{*}$ indicates a significant result $(p 0.05),{ }^{* *}(p 0.01) .{ }^{\mathrm{NS}}=$ result is not significant.

\subsection{Dispersal Dynamics}

The TwoGener method indicated an average pollen dispersal distance $(\mathrm{d})$ ranging from 64.6 to $252.1 \mathrm{~m}$, with a trend of increased dispersal distance when the effective density was reduced from 50 to $10 \%$ census density (Table 3). Evidence for fat-tailed dispersal kernels $(\mathrm{b}<1.0)$ was consistently found for GRNT, LOST, and GFOR, but was absent in CALS and was detected in CALN only when the effective density was set to $50 \%$ census density (Table 3). When using the KinDist approach, the correlated paternity among maternal families did not show a significant decrease with distance for CALN, CALS, or LOST populations (Pearson's product-moment correlation $p$-value $=0.21,0.47$, and 0.69 , respectively). Thus, further analysis using the KinDist method is not recommended for these populations [43]. The estimated dispersal parameters for GRNT and GFOR showed average pollen dispersal distance ranging from 572.8 to $2133.8 \mathrm{~m}$ respectively, and leptokurtic dispersal kernels (i.e., $\mathrm{b}<1.0$ ). Since our goal here was to uncover general pollen dispersal characteristics across the giant sequoia range, we focus the discussion on the TwoGener results, as they provide evidence for more general patterns in the species. 
Table 3. Pollen dispersal parameters obtained using the TwoGener approach.

\begin{tabular}{cccc}
\hline Population & Scale (a) & Shape $(\mathbf{b})$ & Average Distance, $\mathbf{d}(\mathbf{m})$ \\
\hline$(\mathrm{Ne} / \mathrm{N}=0.5)$ & & & \\
CALN & 34.62 & 0.93 & 80.7 \\
CALS & 98.54 & 25.94 & 64.6 \\
GRNT & 0.55 & 0.37 & 74.2 \\
LOST & 34.62 & 0.93 & 80.7 \\
GFOR & 0.004 & 0.22 & 203.0 \\
$(\mathrm{Ne} / \mathrm{N}=0.1)$ & & & \\
CALN & 215.96 & 6.84 & 141.9 \\
CALS & 82.85 & 1.05 & 152.5 \\
GRNT & 4.75 & 0.47 & 129.0 \\
LOST & 1.05 & 0.35 & 213.5 \\
GFOR & 0.37 & 0.31 & 252.1 \\
\hline
\end{tabular}

\section{Discussion}

Our prior work on genetic structure within the range of giant sequoia indicated relatively strong divergence among groves in the northern range (north of the Kings River watershed), despite the close proximity of some of the groves, e.g., the two Calaveras groves (CALN and CALS), Tuolumne and Merced, Nelder and Mariposa [29]. We proposed low rates of seed and pollen dispersal to account for the divergence over such short distances. In the southern range, the groves appeared to be more admixed, which raised questions as to whether dispersal distances might be greater in the south, or whether the increased admixture was a result of a lack of lineage sorting in this more contiguous range.

In the present work, we have addressed gene dispersal by estimating the distances of total gene flow and of pollen dispersal inferred from progeny arrays sampled within groves from the northern and southern range of the species. In addition, we assessed mating system parameters in the same groves to determine whether their size or isolation contributed to any differences in levels of inbreeding through selfing and bi-parental inbreeding. Overall, we found that although giant sequoia is generally an outbreeding species, it exhibits a low degree of selfing and moderate rates of bi-parental inbreeding. The scales of pollen and gene dispersal were consistent across groves, suggesting that dispersal distances for the species are predominantly short, which indicates that most pollination is localized to within groves. The dispersal curves showed evidence of fat-tails, which could indicate potential for some long-distance dispersal events.

\subsection{Mating System and Pollen Pool Diversity}

Consistent with our observations for giant sequoia, outcrossing rates in many windpollinated trees typically range from 90 to $100 \%$ [16,49-53]. In slight contrast, we found higher levels of bi-parental inbreeding in giant sequoia than in many other conifer species $[16,52,54,55]$. Links between inbreeding and population size have been established for some tree species, which can exhibit higher inbreeding (bi-parental or selfing) in smaller populations $[17,52,56]$. From the five groves for which we obtained estimates of inbreeding, we found no evidence of a relationship between grove size and level of inbreeding, despite having data from two groves of less than 25 ha (CALN and LOST). Interestingly, the average bi-parental inbreeding estimated from progeny arrays exceeded the degree of inbreeding ( $\mathrm{F}_{\mathrm{IS}}$-statistic) estimated from adult trees in these five groves using the same microsatellite loci (DeSilva, unpublished data). We believe this difference could be attributable to a post-germination selective filter acting against inbred progeny in natural populations.

We observed low pollen pool diversity in comparison to many other conifers, such as Larix occidentalis $\left(\mathrm{N}_{\mathrm{ep}} \approx 35\right)$, Picea glauca $\left(\mathrm{N}_{\mathrm{ep}}=62-143\right)$, Pinus pinaster $\left(\mathrm{N}_{\mathrm{ep}}=21-56\right)$, and Austrocedrus chilensis (average $\mathrm{N}_{\mathrm{ep}}=13.9$ ) $[16,19,52,57]$, which supports our hypothesis that pollen dispersal in these giant sequoia groves is spatially restricted. However, it should be noted that our $\mathrm{N}_{\mathrm{ep}}$ estimates are similar to those reported for the wind-pollinated 
angiosperm trees Quercus lobata and Nothofagus nervosa [46,51], and our estimate of $\mathrm{N}_{\mathrm{ep}}$ is likely somewhat reduced due to bi-parental inbreeding [58].

\subsection{Evidence for Limited Dispersal}

The high levels of fine-scale spatial genetic structure (FSGS) across the giant sequoia range suggest limited dispersal capacity in this species. Although forest tree species commonly show significant genetic structure, our estimate of the Sp-statistic for giant sequoia was higher than that reported for several other species [59-62]. For instance, in 25 populations of four conifer species, the $\mathrm{Sp}$ values varied from 0.0018 to 0.0035 [62], compared to 0.024-0.044 in giant sequoia. Although peripheral populations (due to small size or lower density) often demonstrate stronger FSGS as compared to core populations $[59,63]$, for giant sequoia the degree of FSGS was fairly consistent across populations (average $\mathrm{Sp}=0.0349$, SD 0.0076). Moreover, we found no relationship between gene dispersal and census population size or density, which points to underlying biological constraints on gene dispersal.

Our results indicate that the majority of pollination in giant sequoia occurs over short distances $<253 \mathrm{~m}$, which is typical for many tree species, including Pinus pinaster, Quercus lobata, Nothofagus nervosa, and Larix decidua $[16,46,48,64]$. Moreover, gene dispersal (a measure of the effective pollen and seed average) also appeared to occur over short distances $<370 \mathrm{~m}$. Assuming an isolation-by-distance model, Crawford [65] showed that the dispersal parameter $\left(\sigma_{e}^{2}\right)$ is comprised of a seed and pollen dispersal component given by $\sigma_{e}^{2}=\sigma_{S e}^{2}+\frac{\sigma_{P e}^{2}}{2}$. Therefore, substituting $370 \mathrm{~m}$ for $\sigma_{e}^{2}$ and $274 \mathrm{~m}$ for $\sigma_{P e}^{2}$, we obtain $244 \mathrm{~m}$ for our estimate of $\sigma_{S e}^{2}$ (seed dispersal), which is only slightly shorter than pollen dispersal. Although we are unable to make comparisons between pollen and gene dispersal for GRNT and LOST, the estimated dispersal parameters show general correspondence. It is also important to note that the TwoGener estimation of pollen dispersal represents a single round of reproduction, whereas the gene dispersal estimates represent evolutionary dispersal. Thus, any direct comparisons should be treated with caution. We did not find any significant differences in pollen or gene dispersal across the range due to census population size or density (number of stems per hectare). However, variation in stand structure could play a role in the movement of pollen. For example, air currents as a vector of pollen movement would be very different over a uniform canopy in more evenaged stands than over a canopy with emergent trees, as would be more typical in an uneven-aged stand. Furthermore, the dynamics of pollen settling would likely vary with stand structure, which could influence the distance of vector transport as well as the correlation of paternity (number of pollen parents per mother tree). These aspects of pollen dispersal interference have received little attention, but studies of a mixed oak beech stand have shown that long-distance dispersal is important in the colonization of gaps, and that understory vegetation presents an important barrier to pollen dispersal [66]. Fire suppression in giant sequoia stands has led to an artificially high density of mid-story trees that could act as a barrier to pollen and, to a lesser extent, seed dispersal. Nevertheless, the strong congruence in dispersal distance in our study suggests the importance of inherent biological controls on dispersal capacity. Interestingly, this finding also suggests that seed and pollen may disperse at similar scales in giant sequoia, which is in contrast to many wind-pollinated trees where pollen travels farther than seed [67-71]. The more limited pollen dispersal in giant sequoia may be a result of less buoyant pollen, as giant sequoia pollen lack the air-filled sacs typical of the members of the Pinaceae (e.g., Pinus spp., Abies spp., Picea spp.) [72-74]. It is important to note that estimates of dispersal using the TwoGener method are closely tied to effective density [75]. Effective density will nearly always be less than the census density of adult trees, as it takes account of variation in reproductive success. Here, we assume that effective density is between 10 and $50 \%$ of census density. Yet, we recognize that no formal studies have examined the effective density of any giant sequoia populations. Our results suggest a general tendency for increased average dispersal when effective density is reduced. Thus, our estimates of 
average dispersal are likely to be underestimates if effective density is lower than $10 \%$ of census density. Additionally, any inaccuracies in the estimation of the census data of adult trees could affect our estimates of effective densities and dispersal distances.

\subsection{Evidence for Long-Distance Pollen Dispersal}

In some conifer species, wind-dispersed pollen can account for extremely longdistance dispersal [17-19,76]. Here, we found leptokurtic pollen dispersal for four out of five populations examined, highlighting the potential for long-distance dispersal in giant sequoia. This finding is consistent with our previous research that indicates connectivity in the southern range of giant sequoia across populations between 2 and $10 \mathrm{~km}$ apart [29]. Yet, this is at odds with the apparent lack of gene flow between adjacent giant sequoia populations in the north [29]. In the southern section of the giant sequoia range, multiple populations are often within $10 \mathrm{~km}$ of each other, potentially allowing for more regional LDD opportunities than in the north where very few populations exist. The reduced kurtosis in the estimated shape of the dispersal kernels for CALN and CALS at $\mathrm{Ne} / \mathrm{N}=0.1$ (Table 3) is potentially influenced by population isolation in the northern range, as any LDD that does not reach a seed would go undetected. Our progeny data from the northern section of the giant sequoia range have important limitations. The indirect TwoGener method works best when few offspring are sampled from many mother trees that are sampled both near and far [75]. Our data had relatively few maternal trees in the CALN and CALS populations. Thus, a more extensive sampling of mother trees, or a detailed parentage analysis, is likely needed to determine the existence of gene-flow across these populations. Empirical studies consistently suggest that "fat-tailed" pollen dispersal curves are typical for many wind-dispersed tree species $[16,17,19,46-48,77]$. Although we found evidence of the leptokurtic dispersal of kernels for giant sequoia pollen, its capacity for LDD may be more limited than many conifers with which it shares a habitat, which have more buoyant pollen. Fat-tailed dispersal curves allow more opportunities for gene flow among fragmented populations [1]. Gene flow can be a crucial factor facilitating population persistence, as it can replenish the diversity lost through genetic drift and introduce new variation into populations, which can be a source of adaptive potential [2,78]. In addition, LDD can be an important factor that can mitigate potential inbreeding effects.

\subsection{Evidence for Demic Structure in Giant Sequoia Groves}

The reproductive dynamics of giant sequoia suggest that demes (local breeding groups) within populations are an important factor influencing changes in genetic diversity over time. Dispersal limitation can result in demic structure within non-selfing species, as mating among close relatives becomes more important. Our data indicate relatively high rates of bi-parental inbreeding that were more or less consistent across groves and highest in GRNT and GFOR groves. We observed predominantly local dispersal, which, coupled with low diversity in the effective pollen pool sampled from mother trees, indicates the importance of reproductive groupings within populations. Moreover, the coupling of high levels of FSGS with predominantly local dispersal can beget the further clustering of related individuals over time. Demic patterns within populations are important because small reproductive neighborhoods can reduce the effective population size and increase the risk of diversity erosion due to genetic drift [13,79]. Moreover, reduced genetic diversity can eventually lead to inbreeding depression, which is a potential threat to population survival [80].

\section{Conclusions}

We present evidence for predominantly local pollen dispersal in giant sequoia and the potential for a limited degree of long-distance dispersal. The spatial restriction of the majority of pollen dispersal has likely influenced the observed strong spatial genetic structure, and created a demic structure within giant sequoia groves. We warn of potential genetic diversity loss in many giant sequoia populations that may be effectively operating 
as smaller reproductive units. Thus, we suggest that small, isolated, and highly structured giant sequoia populations are at highest risk of erosion of genetic diversity. These populations include, but are not limited to, CALN, NELD, GRNT, and DCRK. Although, evidence of fat-tailed dispersal suggests that some of this diversity loss may be mitigated by long-distance gene-flow. Yet, due to the rapid pace of current environmental changes, we suggest that assisting in the movement of genetic resources by planting seedlings from both local and non-local sources in these high-risk populations can be an effective means of enhancing genetic diversity. Due to the presence of a demic structure in giant sequoia populations, seed collections for planting programs should be conducted every 200-300 m to capture the extant diversity of source populations. As climate changes, enhancing extant genetic diversity may be important for the long-term persistence of giant sequoia populations.

Author Contributions: Conceptualization, R.D. and R.S.D.; methodology, R.D. and R.S.D.; formal analysis, R.D.; investigation, R.D.; resources, R.D. and R.S.D.; data curation, R.D.; writing-original draft preparation, R.D.; writing—review and editing, R.D. and R.S.D.; visualization, R.D.; supervision, R.D. and R.S.D.; funding acquisition, R.S.D. All authors have read and agreed to the published version of the manuscript.

Funding: This research received no external funding.

Data Availability Statement: The full seed dataset is available through DRYAD https://doi.org/10 .6078/D1J12B.

Acknowledgments: We sincerely thank Glenn Lunak and Sierra Pacifica Industries for providing seed collections for our study. We also thank Zoe Caron for laboratory assistance with seed germination and DNA extraction. We would also like to thank the reviewers whose feedback helped improve this manuscript.

Conflicts of Interest: The authors declare no conflict of interest.

\section{Appendix A}

Table A1. Total number of genotyped seeds per collection location. Collection locations noted by population code and location ID.

\begin{tabular}{cc}
\hline Seed Collection ID & Number of Seeds Genotyped \\
\hline CALN 1 & 12 \\
\hline CALN 2 & 22 \\
\hline CALN 3 & 17 \\
\hline CALN 4 & 12 \\
\hline CALN 5 & 12 \\
\hline CALN 6 & 12 \\
\hline CALN 7 & 8 \\
\hline CALN 8 & 22 \\
\hline CALN 1 & 12 \\
\hline CALS 1 & 29 \\
\hline CALS 2 & 19 \\
\hline CALS 3 & 16 \\
\hline CALS 4 & 18 \\
\hline CALS 5 & 21 \\
\hline CALS 6 & 23 \\
\hline CALS 7 & 15 \\
\hline
\end{tabular}


Table A1. Cont.

\begin{tabular}{|c|c|}
\hline Seed Collection ID & Number of Seeds Genotyped \\
\hline CALS 8 & 25 \\
\hline CALS 9 & 25 \\
\hline GRNT 1 & 13 \\
\hline GRNT 2 & 29 \\
\hline GRNT 3 & 27 \\
\hline GRNT 4 & 20 \\
\hline GRNT 5 & 20 \\
\hline GRNT 6 & 31 \\
\hline GRNT 7 & 18 \\
\hline GRNT 8 & 17 \\
\hline GRNT 9 & 11 \\
\hline GRNT 10 & 13 \\
\hline GRNT 11 & 13 \\
\hline LOST 1 & 10 \\
\hline LOST 2 & 23 \\
\hline LOST 3 & 25 \\
\hline LOST 4 & 24 \\
\hline LOST 5 & 21 \\
\hline LOST 6 & 26 \\
\hline LOST 7 & 13 \\
\hline LOST 8 & 10 \\
\hline GFOR 1 & 15 \\
\hline GFOR 2 & 20 \\
\hline GFOR 3 & 20 \\
\hline GFOR 4 & 9 \\
\hline GFOR 5 & 30 \\
\hline GFOR 6 & 22 \\
\hline GFOR 7 & 28 \\
\hline GFOR 8 & 21 \\
\hline GFOR 9 & 29 \\
\hline GFOR 10 & 20 \\
\hline GFOR 11 & 35 \\
\hline GFOR 12 & 18 \\
\hline GFOR 13 & 13 \\
\hline GFOR 14 & 34 \\
\hline GFOR 15 & 28 \\
\hline GFOR 16 & 28 \\
\hline GFOR 17 & 30 \\
\hline GFOR 18 & 10 \\
\hline
\end{tabular}




\section{Appendix B}

Table A2. Grove size, number of spatial groups, and distance within the first distance class for populations analyzed with SPAGeDi.

\begin{tabular}{cccc}
\hline Population Code & Grove Size (ha) & $\begin{array}{c}\text { Number of Spatial } \\
\text { Groups }\end{array}$ & $\begin{array}{c}\text { Distance Range within the } \\
\text { First Distance Class (m) }\end{array}$ \\
\hline CALN & 25 & 2 & $0-428$ \\
\hline CALS & 182 & 3 & $0-403$ \\
\hline NELD & 195 & 3 & $0-558$ \\
\hline GRNT & 163 & 3 & $0-293$ \\
\hline RMNT & 1466 & 6 & $0-415$ \\
\hline LOST & 21 & 2 & $0-138$ \\
\hline GFOR & 935 & 6 & $0-767$ \\
\hline ATWL & 542 & 5 & $0-236$ \\
\hline MCTR & 700 & 5 & $0-419$ \\
\hline FMAN & 580 & 5 & $0-456$ \\
\hline LMDW & 138 & 3 & $0-347$ \\
\hline DCRK & 21 & 2 & $0-269$ \\
\hline
\end{tabular}

\section{References}

1. Nathan, R.; Schurr, F.M.; Spiegel, O.; Steinitz, O.; Trakhtenbrot, A.; Tsoar, A. Mechanisms of long-distance seed dispersal. Trends Ecol. Evol. 2008, 23, 638-647. [CrossRef]

2. Kremer, A.; Ronce, O.; Robledo-Arnuncio, J.J.; Guillaume, F.; Bohrer, G.; Nathan, R.; Bridle, J.R.; Gomulkiewicz, R.; Klein, E.K.; Ritland, K.; et al. Long-distance gene flow and adaptation of forest trees to rapid climate change. Ecol. Lett. 2012, 15, 378-392. [CrossRef]

3. Ellstrand, N.C. Is gene flow the most important evolutionary force in plants? Am. J. Bot. 2014, 101, 737-753. [CrossRef]

4. Robledo-Arnuncio, J.J.; Klein, E.K.; Muller-Landau, H.C.; Santamaria, L. Space, time and complexity in plant dispersal ecology. Mov. Ecol. 2014, 2, 16. [CrossRef]

5. Vekemans, X.; Hardy, O.J. New insights from fine-scale spatial genetic structure analyses in plants populations. Mol. Ecol. 2004, 13, 921-935. [CrossRef]

6. Slatkin, M. Gene flow and the Geographic Structure of Natural Populations. Science 1987, 236, 787-792. [CrossRef]

7. Cain, M.L.; Milligan, B.G.; Strand, A.E. Long-distance seed dispersal in plant populations. Am. J. Bot. 2000, 87, 1217-1227. [CrossRef]

8. Rieseberg, L.H.; Burke, J.M. The biological reality of species: Gene flow, selection, and collective evolution. Taxon 2001, 50, 47-67. [CrossRef]

9. Heywood, J.S. Spatial analysis of genetic variation in plant populations. Annu. Rev. Ecol. Syst. 1991, 22, 335-355. [CrossRef]

10. Wright, S. Isolation by distance. Genetics 1943, 28, 114-138.

11. Ellstrand, N.C.; Elam, D.R. Population Genetic Consequences of Small Population Size: Implications for Plant Conservation. Annu. Rev. Ecol. Syst. 1993, 24, 217-242. [CrossRef]

12. Krakowski, J.; Aitken, S.; El-Kassaby, Y. Inbreeding and conservation genetics in whitebark pine. Conserv. Genet. 2003, 4, 581-593. [CrossRef]

13. Willi, Y.; Määttänen, K. The relative importance of factors determining genetic drift: Mating system, spatial genetic structure, habitat and census size in Arabidopsis lyrata. New Phytol. 2011, 189, 1200-1209. [CrossRef]

14. Dow, B.D.; Ashley, M.V. Microsatellite analysis of seed dispersal and parentage of saplings in bur oak, Quercus Macrocarpa. Mol. Ecol. 1996, 5, 615-627. [CrossRef]

15. Bacles, C.F.E.; Burczyk, J.; Lowe, A.J.; Ennos, R.A. Historical and contemporary mating patterns in remnant populations of the forest tree Fraxinus excelsior L. Evolution 2005, 59, 979-990. [CrossRef]

16. De-Lucas, A.; Robledo-Arnuncio, J.; Hidalgo, E.; Gonzalez-Martinez, S.C. Mating system and pollen gene flow in Mediterranean maritime pine. Heredity 2008, 100, 390-399. [CrossRef]

17. Chybicki, I.J.; Dzialuk, A. Bayesian approach reveals confounding effects of population size and seasonality on outcrossing rates in a fragmented subalpine conifer. Tree Genet. Genomes 2014, 10, 1723-1737. [CrossRef]

18. O'Connell, L.M.; Mosseler, A.; Rajora, O.P. Extensive Long-Distance Pollen Dispersal in a Fragmented Landscape Maintains Genetic Diversity in White Spruce. J. Hered. 2007, 98, 640-645. [CrossRef] 
19. Colabella, F.; Gallo, L.A.; Moreno, A.C.; Marchelli, P. Extensive pollen flow in a natural fragmented population of patagonian cypress austrocedrus chilensis. Tree Genet. Genomes 2014, 10, 1519-1529. [CrossRef]

20. Willard, D. A Guide to the Sierra Groves of California; Yosemite Conservancy: San Francisco, CA, USA, 2000.

21. Hartesveldt, R.J.; Harvey, H.T.; Shellhammer, H.S.; Stecker, R.E. The Giant Sequoia of the Sierra Nevada; U.S. Department of the Interior, National Park Service: Washington, DC, USA, 1975.

22. Rundel, P. Habitat Restriction in Giant Sequoia-Environmental Control of Grove Boundaries. Am. Midl. Nat. 1972, 87, 81-99. [CrossRef]

23. Harvey, T.H.; Shellhammer, H.S.; Stecker, R.E. Giant Sequoia Ecology: Fire and Reproduction; Scientific Monograph Series No. 12; U.S. Department of the Interior, National Park Service: Washington, DC, USA, 1980.

24. York, R.; Battles, J.; Heald, R. Edge effects in mixed conifer group selection openings: Tree height response to resource gradients. For. Ecol. Manag. 2003, 179, 107-121. [CrossRef]

25. Shellhammer, H.S.; Shellhammer, T.H. Giant sequoia (Sequoiadendron giganteum Taxodiaceae) seedling survival and growth in the first four decades following managed fires. Madrono 2006, 53, 342-350. [CrossRef]

26. York, R.; Thomas, Z.; Restaino, J. Influence of Ash Substrate Proximity on Growth and Survival of Planted Mixed-Conifer Seedlings. West. J. Appl. For. 2009, 24, 117-123. [CrossRef]

27. Goss, M.; Swain, D.L.; Abatzoglou, J.T.; Sarhadi, A.; Kolden, C.A.; Williams, A.P.; Diffenbaugh, N.S. Climate change is increasing the likelihood of extreme autumn wildfire conditions across California. Environ. Res. Lett. 2020, 15, 094016. [CrossRef]

28. Anderson, R.S. Modern pollen rain within and adjacent to two giant sequoia (Sequoiadendron giganteum) groves, Yosemite and Sequoia national parks, California. Can. J. For. Res. 1990, 20, 1289-1305. [CrossRef]

29. DeSilva, R.; Dodd, R.S. Fragmented and isolated: Limited gene flow coupled with weak isolation by environment in the paleoendemic giant sequoia (Sequoiadendron giganteum). Am. J. Bot. 2020, 107, 45-55. [CrossRef]

30. DeSilva, R.; Dodd, R.S. Development and characterization of microsatellite markers for giant sequoia, Sequoiadendron giganteum (Cupressaceae). Conserv. Genet. Resour. 2014, 6, 173-174. [CrossRef]

31. Doyle, J.J.; Doyle, J.L. Isolation of plant DNA from fresh tissue. Focus 1990, 12, 13-15.

32. York, R.A.; Stephenson, N.L.; Meyer, M.; Hanna, S.; Moody, T.; Caprio, A.C.; Battles, J.J. A Natural Resource Condition Assessment for Sequoia and Kings Canyon National Parks: Appendix 11a_Giant Sequoias; Natural Resource Report NPS/SEKI/NRR-2013/665.11a; National Park Service: Fort Collins, CO, USA, 2013.

33. Kalinowski, S.T.; Wagner, A.P.; Taper, M.L. ml-relate: A computer program for maximum likelihood estimation of relatedness and relationship. Mol. Ecol. Notes 2006, 6, 576-579. [CrossRef]

34. Ritland, K. MLTR: Multilocus Mating System Program, Version 1.1; University of British Columbia: Vancouver, BC, Canada, 1996.

35. Ritland, K. Extensions of models for the estimation of mating systems using $\mathrm{n}$ independent loci. Heredity 2002, 88, 221-228. [CrossRef]

36. Smouse, P.E.; Dyer, R.J.; Westfall, R.D.; Sork, V.L. Two-generation analysis of pollen flow across a landscape. I. Male gamete heterogeneity among females. Evolution 2001, 55, 260-271. [CrossRef] [PubMed]

37. Austerlitz, F.; Smouse, P.E. Two-generation analysis of pollen flow across a landscape; II. Relation between $\Phi(\mathrm{ft})$, pollen dispersal and interfemale distance. Genetics 2001, 157, 851-857.

38. Loiselle, B.A.; Sork, V.L.; Nason, J.; Graham, C. Spatial genetic structure of a tropical understory shrub, Psychotria officinalis (Rubiaceae). Am. J. Bot. 1995, 82, 1420-1425. [CrossRef]

39. Hardy, O.J.; Vekemans, X. Isolation by distance in a continuous population: Reconciliation between spatial autocorrelation and population genetics models. Heredity 1999, 83, 145-154. [CrossRef]

40. Hardy, O.J.; Vekemans, X. SPAGeDi: A versatile computer program to analyse spatial genetic structure at the individual or population levels. Mol. Ecol. Notes 2002, 2, 618-620. [CrossRef]

41. Fenster, C.B.; Vekemans, X.; Hardy, O.J. Quantifying gene flow from spatial genetic structure data in a metapopulation of Chamaecrista fasciculata (leguminosae). Evolution 2003, 57, 995-1007. [CrossRef] [PubMed]

42. Frankham, R. Effective population-size adult-population size ratios in wildlife-A review. Genet. Res. 1995, 66, 95-107. [CrossRef]

43. Robledo-Arnuncio, J.J.; Austerlitz, F.; Smouse, P.E. POLDISP: A software package for indirect estimation of contemporary pollen dispersal. Mol. Ecol. Notes 2007, 7, 763-766. [CrossRef]

44. Robledo-Arnuncio, J.J.; Austerlitz, F.; Smouse, P.E. A new method of estimating the pollen dispersal curve independently of effective density. Genetics 2006, 173, 1033-1045. [CrossRef]

45. Austerlitz, F.; Dick, C.W.; Dutech, C.; Klein, E.K.; Oudu-Muratorio, S.; Smouse, P.; Sork, V.L. Using genetic markers to estimate the pollen dispersal curve. Mol. Ecol. 2004, 13, 937-954. [CrossRef]

46. Marchelli, P.; Smouse, P.E.; Gallo, L.A. Short-distance pollen dispersal for an outcrossed, wind-pollinated southern beech (Nothofagus nervosa (Phil.) Dim. et Mil.). Tree Genet. Genomes 2012, 8, 1123-1134. [CrossRef]

47. Moracho, E.; Moreno, G.; Jordano, P.; Hampe, A. Unusually limited pollen dispersal and connectivity of Pedunculate oak (Quercus robur) refugial populations at the species' southern range margin. Mol. Ecol. 2016, 25, 3319-3331. [CrossRef] [PubMed]

48. Burczyk, J.; Sandurska, E.; Lewandowski, A. Patterns of Effective Pollen Dispersal in Larch: Linking Levels of Background Pollination with Pollen Dispersal Kernels. Forests 2019, 10, 1139. [CrossRef]

49. Burczyk, J.; Adams, W.T.; Shimizu, J.Y. Mating patterns and pollen dispersal in a natural knobcone pine (Pinus attenuata Lemmon.) stand. Heredity 1996, 77, 251-260. [CrossRef] 
50. Wasieliwska, M.; LKlemm, M.; Burczyk, J. Genetic diversity and mating system of Scots pine plus trees. Dendrobiology 2005, 53, 57-62.

51. Sork, V.L.; Dyer, R.J.; Davis, F.W.; Smouse, P.E. Mating patterns in a savanna population of valley oak (Quercus lobata Neé). In Proceedings of the Fifth Symposium on Oak Woodlands: Oaks in California's Changing Landscape, San Diego, CA, USA, 22-25 October 2001; Pacific SW Research Station, US Forest Service, USDA: San Diego, CA, USA, 2002; pp. 427-439.

52. O'Connell, L.M.; Mosseler, A.; Rajora, O.P. Impacts of forest fragmentation on the mating system and genetic diversity of white spruce (Picea glauca) at the landscape level. Heredity 2006, 97, 418-426. [CrossRef]

53. Bower, A.D.; Aitken, S.N. Mating system and inbreeding depression in whitebark pine (Pinus albicaulis Engelm.). Tree Genet. Genomes 2007, 3, 379-388. [CrossRef]

54. Ledig, F.T.; Hodgskiss, P.D.; Johnson, D.R. Genic diversity, genetic structure, and mating system of Brewer spruce (Pinaceae), a relict of the Arcto-Tertiary forest. Am. J. Bot. 2005, 92, 1975-1986. [CrossRef]

55. Mantovani, A.; Morellato, L.P.C.; Dos Reis, M.S. Internal Genetic Structure and Outcrossing Rate in a Natural Population of Araucaria angustifolia (Bert.) O. Kuntze. J. Hered. 2006, 97, 466-472. [CrossRef]

56. Rajora, O.P.; Mosseler, A.; Major, J.E. Mating system and reproductive fitness traits of eastern white pine (Pinus strobus) in large, central versus small, isolated, marginal populations. Can. J. Bot. 2002, 80, 1173-1184. [CrossRef]

57. El-Kassaby, Y.A.; Jaquish, B. Population density and mating pattern in western larch. J. Hered. 1996, 87, 438-443. [CrossRef]

58. Austerlitz, F.; Smouse, P.E. Two-generation analysis of pollen flow across a landscape. III. Impact of within-population structure. Genet. Res. 2001, 78, 271-278. [CrossRef] [PubMed]

59. de-Lucas, A.I.; Gonzalez-Martinez, S.C.; Vendramin, G.G.; Hidalgo, E.; Heuertz, M. Spatial genetic structure in continuous and fragmented populations of Pinus pinaster Aiton. Mol. Ecol. 2009, 18, 4564-4576. [CrossRef]

60. Aleksic, J.M.; Piotti, A.; Geburek, T.; Vendramin, G.G. Exploring and conserving a "microcosm": Whole-population genetic characterization within a refugial area of the endemic, relict conifer Picea omorika. Conserv. Genet. 2017, 18, 777-788. [CrossRef]

61. Eliades, N.H.; Fady, B.; Gailing, O.; Leinemann, L.; Finkeldey, R. Significant patterns of fine-scale spatial genetic structure in a narrow endemic wind-dispersed tree species, Cedrus brevifolia Henry. Tree Genet. Genomes 2018, 14, 15. [CrossRef]

62. Mosca, E.; Di Pierro, E.A.; Budde, K.B.; Neale, D.B.; González-Martínez, S.C. Environmental effects on fine-scale spatial genetic structure in four Alpine keystone forest tree species. Mol. Ecol. 2018, 27, 647-658. [CrossRef]

63. Gapare, W.J.; Aitken, S.N. Strong spatial genetic structure in peripheral but not core populations of Sitka spruce [Picea sitchensis (Bong.) Carr.]. Mol. Ecol. 2005, 14, 2659-2667. [CrossRef]

64. Pluess, A.R.; Sork, V.L.; Dolan, B.; Davis, F.W.; Grivet, D.; Merg, K.; Papp, J.; Smouse, P.E. Short distance pollen movement in a wind-pollinated tree, Quercus lobata (Fagaceae). For. Ecol. Manag. 2009, 258, 735-744. [CrossRef]

65. Crawford, T.J. The estimation of neighborhood parameters for plant populations. Heredity 1984, 52, 273-283. [CrossRef]

66. Millerón, M.; López de Heredia, U.; Lorenzo, Z.; Perea, R.; Dounavi, A.; Alonso, J.; Gil, L.; Nanos, N. Effect of canopy closure on pollen dispersal in a wind-pollinated species (Fagus sylvatica L.). Plant Ecol. 2012, 213, 1715-1728.

67. Latta, R.G.; Linhart, Y.B.; Fleck, D.; Elliot, M. Direct and indirect estimates of seed versus pollen movement within a population of Ponderosa pine. Evolution 1998, 52, 61-67. [CrossRef]

68. Schuster, W.S.F.; Mitton, J.B. Paternity and gene dispersal in limber pine (Pinus flexilis James). Heredity 2000, 84, 348-361. [CrossRef]

69. Heuertz, M.; Vekemans, X.; Hausman, J.F.; Palada, M.; Hardy, O.J. Estimating seed versus pollen dispersal from spatial genetic structure in the common ash. Mol. Ecol. 2003, 12, 2483-2495. [CrossRef]

70. Chybicki, I.J.; Burczyk, J. Realized gene flow within mixed stands of Quercus robur L. and Q. petraea (Matt.) L. revealed at the stage of naturally established seedling. Mol. Ecol. 2010, 19, 2137-2151. [CrossRef]

71. Sork, V.; Smouse, P.; Grivet, D.; Scofield, D. Impact of asymmetric male and female gamete dispersal on allelic diversity and spatial genetic structure in valley oak (Quercus lobata Nee). Evol. Ecol. 2015, 29, 927-945. [CrossRef]

72. Ting, W.S. The Saccate Pollen Grains of Pinaceae Mainly of California. Grana 1965, 6, 270-289. [CrossRef]

73. Bortenschlager, S. Aspects of pollen morphology in the cupressaceae. Grana 1990, 29, 129-138. [CrossRef]

74. Schwendemann, A.B.; Wang, G.; Mertz, M.L.; McWilliams, R.T.; Thatcher, S.L.; Osborn, J.M. Aerodynamics of saccate pollen and its implications for wind pollination. Am. J. Bot. 2007, 94, 1371-1381. [CrossRef]

75. Smouse, P.E.; Sork, V.L. Measuring pollen flow in forest trees: An exposition of alternative approaches. For. Ecol. Manag. 2004, 197, 21-38. [CrossRef]

76. Robledo-Arnuncio, J.J. Wind pollination over mesoscale distances: An investigation with Scots pine. New Phytol. 2011, 190, 222-233. [CrossRef]

77. Robledo-Arnuncio, J.J.; Gil, L. Patterns of pollen dispersal in a small population of Pinus sylvestris L. revealed by total-exclusion paternity analysis. Heredity 2005, 94, 13-22. [CrossRef] [PubMed]

78. Young, A.; Boyle, T.; Brown, T. The population genetic consequences of habitat fragmentation for plants. Trends Ecol. Evol. 1996, 11, 413-418. [CrossRef]

79. Whitlock, M.C.; Barton, N.H. The Effective Size of a Subdivided Population. Genetics 1997, 146, 427-441. [PubMed]

80. Frankham, R. Inbreeding and extinction: A threshold effect. Conserv. Biol. 1995, 9, 792-799. [CrossRef] 